\title{
Violence in hot weather: Will climate change exacerbate rates of violence in South Africa?
}

Worldwide, violence claims more than 1.4 million lives each year, accounting for 1 in 40 of all deaths globally. ${ }^{[1]}$ Alarmingly, South Africa (SA) recorded a homicide rate of 35.8 per 100000 people in $2017 / 18,{ }^{[2]}$ which is the second highest rate in sub-Saharan Africa and among the top 10 in the world, including among countries at war. ${ }^{[1]}$

While violence in SA has been attributed to the unique historical, social and economic characteristics of the country, ${ }^{[3]}$ the potential contribution of physical environmental factors, such as heat, has largely been ignored. Understanding connections between heat and violence is increasingly important as we witness the warming of our planet, and anticipate more intense and longer-lasting heatwaves in the coming decades. Exposure to extreme heat is already common in many parts of SA; temperatures frequently exceed $40^{\circ} \mathrm{C}$ in Northern Cape Province, for example, but can also reach those levels in areas with a more temperate climate, such as Johannesburg. In this editorial, we examine evidence on the connections between temperature and interpersonal violence, and consider the implications of these connections for SA.

\section{Evidence of interactions between heat and interpersonal violence}

Meteorological conditions, especially temperature, can profoundly influence a person's physiology and behaviour. Heat exposure has a range of physiological sequelae, affecting levels of comfort, emotional stability and sense of wellbeing. ${ }^{[4]}$ Being in an uncomfortably hot environment foments irritability and aggressive thoughts, and reduces positive emotions such as joy and happiness. ${ }^{[4,5]}$ Men appear to be particularly sensitive to the effects of heat on aggression. ${ }^{[6]}$ Hot weather also alters behaviours, for example resulting in people tending to congregate outdoors, with increased opportunities for contact crimes and violence. ${ }^{[7]}$ Additionally, alcohol use, a potent trigger for violence, can increase during hot weather, while dehydration, more common on hot days, is associated with mood disturbance, confusion and anger. ${ }^{[8]}$ It is therefore plausible that together these physiological and behavioural pathways may increase the likelihood of violence, particularly violence committed with the intention of harming other persons rather than violence where the aim is primarily to gain assets, such as robberies.

The potential for heat to trigger violence is supported by a number of population-level studies which found that warmer regions of the globe generally have the highest rates of violence, as do warmer parts of individual countries, even after controlling for potential confounding variables. ${ }^{[4]}$ In most studies, rates of violence are highest in the summer months, especially in hot summers. ${ }^{[9,10]}$ In addition, most time-series studies that compare temperature and rates of violence over different time periods indicate that levels of homicide and other forms of violence increase during hot weather, relative to colder periods in the same setting (Table 1). Associations between temperature and violence are not necessarily linear, however. Correlations are often curvilinear or an inverted U-shape, where rates of violence increase in a linear fashion once temperatures rise above moderately high levels, then plateau at a certain threshold, and decline as temperatures become unbearable and people prefer 'flight' or 'escape' rather than conflict. ${ }^{[1]}$
Importantly, the degree to which heat impacts on violence varies across settings and is contingent on factors such as gun control, gender inequalities, substance abuse and socioeconomic vulnerability. One study in the USA, for example, showed that associations between heat and violence were considerably stronger in areas with the highest levels of social disadvantage. ${ }^{[12]}$ Some studies have also noted that women suffer higher levels of physical and sexual violence in hot weather. ${ }^{[13,14]}$ This is especially concerning in SA given the already high background levels of violence against women and a femicide rate among the highest in the world ${ }^{[15]}$ Of note, the pathways leading to these forms of violence are complex and driven by a number of factors, especially social norms that cast aggression and dominance as defining traits of masculinity. ${ }^{[16]}$ Raised temperatures alone therefore cannot explain elevated levels of gender-based violence, but may rather act as a trigger for individual violent episodes.

Surprisingly few studies have examined the impact of temperature on rates of violence in SA, despite a wealth of available data. A study using data from all 1158 police wards in SA documented higher levels of violence, including homicides, during periods of high temperature. ${ }^{[17]}$ In Tshwane, Gauteng Province, a study assessed 5 years of temperature and crime data and found that the mean number of violent crime incidents was about $50 \%$ higher on high-temperature days compared with low-temperature days and random days selected from the dataset after the warmest and coldest days had been extracted. ${ }^{[18]}$ Another study in the same area noted seasonal patterns in crime, with violence most frequent in the summer months. ${ }^{[10]}$ Seasonal quirks, however, such as elevated alcohol consumption and behavioural changes around Christmas, may partially explain the findings of the latter study.

\section{Heat-related violence in SA: Implications for policy and research in a warming climate}

Climate change brings concerns about heat-related violence to the fore. We illustrate this by summing evidence on the associations between temperature and homicides, and outlining the potential implications of those findings for SA (Table 1). Sixteen articles were located through targeted searches of Google Scholar and from experts in the field.

Nine of the 16 studies reported an increase in homicides with a rise in temperature. While the remaining studies did not detect a significant association, they were all in the direction of a positive effect. Effect size ranged widely, from small effects in some studies in the USA to an estimated $17 \%$ increase in homicides per year in Africa were the temperature to increase by $1^{\circ} \mathrm{C} \cdot{ }^{[19]}$ Based on the findings of these studies and using a conservative estimate of a $4-5 \%$ increase in homicides per degree rise in temperature, we estimate that the current number of homicides per year in South Africa $(20336)^{[2]}$ will increase by between 800 and 1000 should the temperature in the country rise by $1^{\circ} \mathrm{C}$. Additional modelling work using empirical data in SA is needed to refine this estimate and to adjust for other mediating factors.

The heat-violence nexus has important implications for policy and research in SA. Firstly, analysis of existing data could identify specific areas and populations at high risk for heat-related violence. 
Table 1. Associations between temperature and homicide rates in 16 studies

\begin{tabular}{|c|c|c|c|c|}
\hline Author, date & Years of study & Study population & $\begin{array}{l}\text { Study results (changes in homicide rates } \\
\text { with temperature) }\end{array}$ & Direction of effect \\
\hline $\begin{array}{l}\text { Harp and Karnauskas, } \\
2018^{[25]}\end{array}$ & $1979-2016$ & USA, 49 states & $\begin{array}{l}\text { In } 60 \text { comparisons ( } 5 \text { regions of the country, each over } \\
12 \text { months), } 6 \text { had a significant positive effect, and a } \\
\text { further } 44 \text { were NS, but in a positive direction }\end{array}$ & $\begin{array}{l}\text { NS, but in direction } \\
\text { of effect }\end{array}$ \\
\hline $\begin{array}{l}\text { Blakeslee and } \\
\text { Fishman, 2018 }\end{array}$ & $1971-2000$ & India, whole country & $\begin{array}{l}\text { Percent change per } 100000 \text { people with a temperature } \\
1 \text { SD above the long-run mean: } 1990-20003.6 \% \\
(p<0.05), 1980-1990-0.2 \%(\mathrm{NS}), 1970-19804 \% \\
(\mathrm{NS}) . \text { Pre-monsoon } 0.1 \%(\mathrm{NS}), \text { monsoon } 2.1 \%(\mathrm{NS}) \text {, } \\
\text { post-monsoon } 0.1 \%(\mathrm{NS})\end{array}$ & $\begin{array}{l}\text { NS, but in direction } \\
\text { of effect }\end{array}$ \\
\hline $\begin{array}{l}\text { Bruederle et al., } \\
2017^{[17]}\end{array}$ & $2001-2012$ & SA, whole country & $\begin{array}{l}\text { Coefficient }=0.015(p<0.01) \text {, based on } 418327 \\
\text { murders in all } 1158 \text { police wards }\end{array}$ & + \\
\hline Hu et al., 2017 & $2009-2014$ & China, Tanshan & Regression analysis $R^{2}=0.10(p<0.05)$ & + \\
\hline Mapou et al., 2017 & $2009-2013$ & $\begin{array}{l}\text { USA, Chicago, } \\
\text { Houston, } \\
\text { Philadelphia, Seattle }\end{array}$ & $\begin{array}{l}\text { Homicide rates } 85 \% \text { higher in } 75 \text { th temperature } \\
\text { percentile than in } 25 \text { th }(95 \% \mathrm{CI}-53-731 ; p=0.38)\end{array}$ & $\begin{array}{l}\text { NS, but in direction } \\
\text { of effect }\end{array}$ \\
\hline Michel et al., 2016 $6^{[29]}$ & $2007-2013$ & $\begin{array}{l}\text { USA, Maryland, } \\
\text { Baltimore }\end{array}$ & $\begin{array}{l}\text { Correlation coefficient } r=0.071 \text { per day }(p=0.002) \text {. } \\
\text { Incident rate ratio per day for a } 1^{\circ} \mathrm{C} \text { increase, } \\
\text { controlling for other weather variables }=1.01(95 \% \\
\text { CI } 0.997-1.02 ; p=0.12)\end{array}$ & $\begin{array}{l}\text { NS, but in direction } \\
\text { of effect }\end{array}$ \\
\hline $\begin{array}{l}\text { Mares and Moffett, } \\
2016^{[19]}\end{array}$ & $1995-2012$ & $\begin{array}{l}57 \text { countries across } \\
\text { the world }\end{array}$ & $\begin{array}{l}\text { Increase in homicides per } 1^{\circ} \mathrm{C} \text { increase a year: globally } \\
5.9 \%(p<0.05) \text {, Africa } 17.9 \%(p<0.05) \text {, North America, } \\
\text { Australia, New Zealand } 2.8 \%(p<0.05) \text {, Asia } 1.8 \% \text { (NS), } \\
\text { Europe } 1.8 \% \text { (NS), former USSR }-0.3 \% \text { (NS), Latin } \\
\text { America } 4.4 \% \text { (NS) }\end{array}$ & + \\
\hline Mares, $2013^{[30]}$ & $1990-2009$ & USA, St Louis & $\begin{array}{l}0.73 \% \text { (NS) increase in homicides per } 1^{\circ} \mathrm{F} \text { per year. } \\
\text { Annual homicides ( } 18906 \text { ) would rise by } 138 \text { /year }\end{array}$ & $\begin{array}{l}\text { NS, but in direction } \\
\text { of effect }\end{array}$ \\
\hline Ranson, 2012 $2^{[31]}$ & $1960-2009$ & USA, 49 states & $\begin{array}{l}\text { Compared with temperatures of } 60-69^{\circ} \mathrm{F} \text {, homicides } \\
\text { per day increased by } 0.001 \text { at } 80-89^{\circ} \mathrm{F}(p<0.05) \text { and } \\
\text { by } 0.002 \text { per day at } 90-99^{\circ} \mathrm{F}(p<0.05) \text {. No change at a } \\
\text { temperature at } \geq 100^{\circ} \mathrm{F} \text {. An inverted } \mathrm{U} \text { with inflection } \\
\text { at } 100^{\circ} \mathrm{F} \text {. Between } 2010 \text { and } 2099 \text {, climate change } \\
\text { may cause an additional } 23855-29894 \text { homicides } \\
\text { (estimates from two climate models), a } 3.1 \% \text { increase. }\end{array}$ & + \\
\hline $\begin{array}{l}\text { Gamble and Hess, } \\
2012^{[32]}\end{array}$ & $1993-1999$ & USA, Texas, Dallas & $\begin{array}{l}\text { Mean daily rate for homicide } 0.06 \text { per } 100000 ; 0.00059 \\
(p<0.01) \text { increase per day for every } 1^{\circ} \mathrm{F} \text { increase in } \\
\text { mean temperature. Inverted } \mathrm{U} \text {-shape with inflection } \\
\text { point at } 90^{\circ} \mathrm{F}\end{array}$ & + \\
\hline $\begin{array}{l}\text { McDowall et al., } \\
2012^{[33]}\end{array}$ & $1977-2000$ & USA, 88 cities & Coefficient $=0.017(\mathrm{NS})$ & $\begin{array}{l}\text { NS, but in direction } \\
\text { of effect }\end{array}$ \\
\hline $\begin{array}{l}\text { Anderson and DeLisi, } \\
2011^{[34]}\end{array}$ & $1950-2008$ & USA, whole country & $\begin{array}{l}4.19 \text { additional serious and deadly assaults per } 100000 \\
\text { people for a } 1^{\circ} \mathrm{F} \text { increase in average annual temperature } \\
(p<0.05) .12780 \text { additional serious deadly assaults per } \\
\text { year }\end{array}$ & + \\
\hline $\begin{array}{l}\text { Simister J and } \\
\text { van de Vliert, 2005 }\end{array}$ & $1977-2001$ & $\begin{array}{l}\text { Pakistan, whole } \\
\text { country }\end{array}$ & $\begin{array}{l}\text { Regression coefficient }=0.0085(p<0.01) \\
\text { Approximately linear correlation, no decline at higher } \\
\text { temperatures }\end{array}$ & + \\
\hline Ceccato, $2005^{[9]}$ & $\begin{array}{l}\text { Jul } 2001 \text { - Jun } \\
2002\end{array}$ & Brazil, São Paulo & $\begin{array}{l}\text { Ordinary least-squares regression coefficient }=0.16 \\
(p<0.05) . \text { Homicides tended to be highest on hot } \\
\text { evenings during warm weekends }\end{array}$ & + \\
\hline $\begin{array}{l}\text { Rotton and Cohn, } \\
2003^{[36]}\end{array}$ & $1960-1998$ & USA, whole country & $\begin{array}{l}\text { Many homicides at low and at high temperatures } \\
\text { (homicides at low temperatures driven by high rates of } \\
\text { homicide in Alaska). Homicides regression coefficient } \\
=0.02 \text { (NS). U-shaped with a minimum at } 50.6^{\circ} \mathrm{F}\end{array}$ & $\begin{array}{l}\text { NS, but in direction } \\
\text { of effect }\end{array}$ \\
\hline $\begin{array}{l}\text { Anderson et al., } \\
1997^{[14]}\end{array}$ & $1950-1995$ & USA, whole country & $\begin{array}{l}\text { Regression coefficient }=0.46(p<0.05) \text {. Annual increase } \\
\text { in homicides and serious assaults }=3.68 / 100000 \\
\text { people for a } 1^{\circ} \mathrm{F} \text { increase }(p<0.05) \text {. Linear, no threshold } \\
\text { effect noted }\end{array}$ & + \\
\hline
\end{tabular}


A more detailed understanding of heat-violence pathways could help identify practical ways of ameliorating the 'felt effects of heat' and thus violence in these 'hot spots'. For example, air conditioning and fans could be used in 'cooling zones' operating in selected areas in specific workplaces, schools and prisons at high risk. This hypothesis may be worth testing given the potential scale of the problem in SA. Evidence from a study in the USA also lends support to the hypothesis. In that study, aggressive crime rates were lower in neighbourhoods where air conditioning use was more frequent. ${ }^{[20]}$

Secondly, a more nuanced understanding of heat-health interactions could help inform measures taken during heatwaves, where, for example, the police force could be primed to expect more cases of violence on days with high temperatures. Similarly, health services, especially trauma units, could prepare for an increased number of assault cases. As an aside, people with mental health disorders require specific attention during heatwaves, owing to links between mental health and violence, and also because many studies have noted connections between suicide rates and high temperatures. ${ }^{[21]}$ Climate services could therefore incorporate messaging on violence prevention and on the effects of heat on mental health into their public communication during heatwaves.

Heat-aggression pathways may also impact on road traffic injuries, especially among young male drivers. ${ }^{[22,23]}$ This association warrants further investigation. It may, for example, be worth evaluating whether providing air conditioning in combi taxis during heatwaves would reduce driver aggression and improve driver performance. Lastly, quantifying the burden of climate-sensitive conditions, such as violence, could help mobilise support for initiatives to counter the brown energy policies of the SA government.

\section{Conclusions}

Evidence increasingly indicates that the propensity for interpersonal violence may increase in uncomfortably hot temperatures. Countries like SA, which already have high levels of violence and a rapidly warming climate, may be particularly vulnerable to this underappreciated consequence of climate change. There may be a considerable increase in the number of cases of homicide and other forms of violence per year should the mean temperature rise by $1^{\circ} \mathrm{C}$, signalling the potential for an even greater burden of violence, centred on already vulnerable groups. Moreover, other consequences of climate change, such as extreme weather events, 'eco-migration' and conflict over food and water, could in themselves raise levels of collective violence and transnational conflict. ${ }^{[24]}$

Importantly, physical environmental triggers of violence, such as heat, are set against the backdrop of complex social processes, poor governance and historical circumstances that influence violence in SA. ${ }^{[3]}$ Clearly, more detailed assessments are required of the linkages between heat and violence in SA, and interactions between these and other factors. Such analyses may have important practical implications for violence-prevention strategies in the country, and indeed globally.

\section{Matthew F Chersich, ${ }^{1}$ Callum Patrick Swift, ${ }^{2}$ Ian Edelstein, ${ }^{3}$ Greg Breetzke, ${ }^{4}$ Fiona Scorgie, ${ }^{1}$ Francois Schutte, ${ }^{4}$ Caradee Y Wright ${ }^{4,5}$}

\footnotetext{
${ }^{1}$ Wits RHI (Wits Reproductive Health and HIV Institute), Faculty of Health Sciences, University of the Witwatersrand, Johannesburg, South Africa

${ }^{2}$ Tallaght University Hospital, Dublin, Ireland

${ }^{3}$ Human Sciences Research Council, Pretoria, South Africa
}

${ }^{4}$ Department of Geography, Geoinformatics and Meteorology, Faculty of Natural and Agricultural Sciences, University of Pretoria, South Africa Environment and Health Research Unit, South African Medical Research Council, Pretoria, South Africa

1. World Health Organization. Global Health Estimates 2016: Deaths by Cause, Age, Sex, by Country an by Region, 2000 - 2016. Geneva: WHO, 2018. https://www.who.int/healthinfo/global_burden_disease estimates/en/index1.html (accessed 2 June 2019).

2. South African Police Service (SAPS). Crime statistics. 2018. https://www.saps.gov.za/services crimestats.php (accessed 2 June 2019).

3. Altbeker A. A Country At War With Itself: South Africa’s Crisis of Crime. Johannesburg: Jonathan Ball Publishers, 2007.

4. Miles-Novelo AJ, Anderson CA. Climate change and psychology: Effects of rapid global warming on

Miles-Novelo A], Anderson CA. Climate change and psychology: Effects of rapid global warming on
violence and aggression. Curr Clim Change Rep 2019;5(1):35-46. https://doi.org/10.1007/s40641-019violence

5. Plante C, Allen JJ, Anderson CA. Likely effects of rapid climate change on violence and conflict. In: Oglesby L, ed. The Oxford Research Encyclopedia of Climate Science. Oxford: Oxford University Press, 2017.

6. Xiong J, Lian ZW, Zhou X, You JX, Lin YB. Investigation of gender difference in human respons to temperature step changes. Physiol Behav 2015;151:426-440. https://doi.org/10.1016/j. physbeh.2015.07.037

7. Cohen L, Felson M. Social change and crime rate trends: A routine activity approach. Am Sociol Rer 1979;44(4):588-608. https://doi.org/10.2307/2094589

8. Ely BR, Sollanek KJ, Cheuvront SN, Lieberman HR, Kenefick RW. Hypohydration and acute thermal stress affect mood state but not cognition or dynamic postural balance. Eur J Appl Physiol 2013;113(4):1027-1034. https://doi.org/10.1007/s00421-012-2506-6

9. Ceccato V. Homicide in São Paulo, Brazil: Assessing spatial-temporal and weather variations.J Environ Psychol 2005;25(3):307-321. https:///doi.org/10.1016//.jenvp.2005.07.002

10. Breetzke GD, Cohn EG. Seasonal assault and neighborhood deprivation in South Africa: Some Breetzke GD, Cohn EG. Seasonal assault and neighborhood deprivation in South Africa: Some
preliminary findings. Environ Behav 2012;44(5):641-667. https://doi.org/10.1177/0013916510397758 preliminary findings. Environ Behav 2012;44(5):641-667. https://doi.org/10.1177/0013916510397758
Rotton J, Cohn EG. Violence is a curvilinear function of temperature in Dallas: A replication. J Pers Soc Psychol 2000;78(6):1074-1081. https://doi.org/10.1037/0022-3514.78.6.1074

12. Mares D. Climate change and levels of violence in socially disadvantaged neighborhood groups. J Urban Health 2013;90(4):768-783. https://doi.org/10.1007/s11524-013-9791-1

13. Michael RP, Zumpe D. An annual rhythm in the battering of women. Am J Psychiatry 1986;143(5):637 640. https://doi.org/10.1176/ajp.143.5.637

14. Anderson CA, Bushman BJ, Groom RW. Hot years and serious and deadly assault: Empirical tests of the heat hypothesis. J Pers Soc Psychol 1997;73(6):1213-1223. https://doi.org/10.1037/00223514.73.6.1213

15. Abrahams N, Mathews S, Martin LJ, Lombard C, Jewkes R. Intimate partner femicide in South Africa in 1999 and 2009. PLoS Med 2013;10(4):e1001412. https://doi.org/10.1371/journal.pmed.1001412

6. Jewkes R, Flood M, Lang J. From work with men and boys to changes of social norms and reduction of inequities in gender relations: A conceptual shift in prevention of violence against women and girls. of inequities in gender relations: A conceptual shift in prevention of violence against
Lancet 2015;385(9977):1580-1589. https:///oi.org/10.1016/S0140-6736(14)61683-4

17. Bruederle A, Peters J, Roberts G. Weather and crime in South Africa. Ruhr Economic Papers \#739. Essen: Leibniz-Institut für Wirtschaftsforschung, 2017. https://doi.org/10.4419/86788859

18. Schutte FH, Breetzke GD. The influence of extreme weather conditions on the magnitude and spatial distribution of crime in Tshwane (2001 - 2006). S Afr Geogr J 2018;100(3):364-377. https://doi.org/
detal 10.1080/03736245.2018.1498384

19. Mares D, Moffett K. Climate change and interpersonal violence: A 'global' estimate and regional inequities. Clim Change 2016;135(2):297-310. https://doi.org/10.1007/s10584-015-1566-0

20. Harries K, Stadler S. Determinism revisited: Assault and heat stress in Dallas. Environ Behav 1983;15(2):235-256. https://doi.org/10.1177/0013916583152006

21. Gao J, Cheng Q, Duan J, et al. Ambient temperature, sunlight duration, and suicide: A systematic review and meta-analysis. Sci Total Environ 2019;646:1021-1029. https://doi.org/10.1016/j. scitotenv.2018.07.098

22. Nofal FH, Saeed AAW. Seasonal variation and weather effects on road traffic accidents in Riyadh City. Public Health 1997;111(1):51-55. https://doi.org/10.1038/s.ph. 1900297

23. Wyon DP, Wyon I, Norin F. Effects of moderate heat stress on driver vigilance in a moving vehicle. Wyon DP, Wyon I, Norin F. Effects of moderate heat stress on driver vigil
Ergonomics 1996;39(1):61-75. https:///oi.org/10.1080/00140139608964434

24. Burke MB, Miguel E, Satyanath S, Dykema JA, Lobell DB. Warming increases the risk of civil war in Africa. Proc Natl Acad Sci U S A 2009;106(49):20670-20674. https://doi.org/10.1073/pnas.0907998106 Africa. Proc Natl Acad Sci U S A 2009;106(49):20670-20674. https://doi.org/10.1073/pnas.0907998106 Harp RD, Karnauskas KB. The influence of interannual climate variability on regional violent crine
rates in the United States. GeoHealth 2018;2(11):356-369. https://doi.org/10.1029/2018GH000152 rates in the United States. GeoHealth 2018;2(11):356-369. https://doi.org/10.1029/2018GH000152
. Blakeslee DS, Fishman R. Weather shocks, agriculture, and crime evidence from India. J Hum Resou 2018;53(3):750-782. https://doi.org/10.2139/ssrn.2428249

27. Hu X, Wu J, Chen P, Sun T, Li D. Impact of climate variability and change on crime rates in Tangshan, China. Sci Total Environ 2017;609:1041-1048. https://doi.org/10.1016/j.scitotenv.2017.07.163

28. Mapou AEM, Shendell D, Ohman-Strickland P, et al. Environmental factors and fluctuations in daily crime rates. J Environ Health 2017;80(5):8-22.

29. Michel SJ, Wang $\mathrm{H}$, Selvarajah $\mathrm{S}$, et al. Investigating the relationship between weather and violence in Baltimore, Maryland, USA. Injury 2016;47(1):272-276. https://doi.org/10.1016/j.injury.2015.07.006

30. Mares D. Climate change and crime: Monthly temperature and precipitation anomalies and crime rates in St. Louis, MO 1990 - 2009. Crime Law Soc Change 2013;59(2):185-208. https://doi.org/10.1007/ s10611-013-9411-8

31. Ranson M. Crime, weather, and climate change. Harvard Kennedy School M-RCBG Associate Working Paper Series No. 8. 2012. https://www.hks.harvard.edu/centers/mrcbg/publications/awp/ awp8 (accessed 2 June 2019).

32. Gamble JL, Hess JL. Temperature and violent crime in Dallas, Texas: Relationships and implications of climate change. West J Emerg Med 2012;13(3):239-246. https://doi.org/10.5811/westjem.2012.3.1174 33. McDowall D, Loftin C, Pate M. Seasonal cycles in crime, and their variability. J Quant Criminol 2012;28(3):389-410. https://doi.org/10.1007/s10940-011-9145-7

34. Anderson CA, DeLisi M. Implications of global climate change for violence in developed and developing countries. In: Forgas J, Kruglanski A, Williams K, eds. The Psychology of Social Conflict and Aggression. New York: Psychology Press, 2011:249-265.

35. Simister J, van de Vliert E. Is there more violence in very hot weather? Tests over time in Pakistan, and across countries worldwide. Pakistan J Meteorol 2005;2(4):51-66.

36. Rotton J, Cohn EG. Global warming and U.S. crime rates: An application of routine activity theory. Environ Behav 2003;35(6):802-825. https://doi.org/10.1177/0013916503255565

S Afr Med J 2019;109(7):447-449. DOI:10.7196/SAMJ.2019.v109i7.14134 